\title{
SPATIO-TEMPORAL ANALYSIS OF SHEEP AND GOATS GRAZING IN DIFFERENT FORAGE RESOURCES OF NORTHERN GREECE
}

\author{
Christakis EVANGELOU ${ }^{1, *}$, \\ Maria YIAKOULAKI ${ }^{1} \&$ Vasilios PAPANASTASIS ${ }^{1}$
}

\begin{abstract}
Grazing animals explore different forage resources to satisfy their daily nutrient needs, following specific spatial and temporal patterns throughout the year. In this study four different flocks of sheep and goats (two of each species) were selected to record their spatial location with a handheld GPS during spring, summer and winter. At the same time, three animals in each flock were followed to study their grazing activities by direct observation. These data with the time information and a detailed land use map were manipulated in a GIS to assign animal activities to different forage resources. Sheep and goats were travelling long distances (7.5 km and $9.0 \mathrm{~km}$, respectively) to satisfy their nutritional needs throughout the year. They were found to graze in two main forage resources, rangelands (grasslands, shrublands and forest ranges) and agricultural land (fallow land, stubble fields and temporary pastures). Both grazer species spent significantly less time $(\mathrm{P} \leq 0.05)$ feeding in rangelands $(38.9 \%$ \& $18.1 \%)$ than in agricultural land (63.6\% \& 53.4\%) during spring and summer. It appears that a heterogeneous landscape is necessary for supporting extensive farming systems of small ruminants since rangelands and agricultural land complement each other in providing forage throughout the year. Key words: Flocks, GIS, GPS, grazing activities, rangelands, small ruminants.
\end{abstract}

\begin{abstract}
Izvleček
Pašne živali se hranijo z različnimi krmnimi rastlinami, da zadostijo svojim dnevnim potrebam po hrani, pri tem sledijo različnim prostorskim in časovnim vzorcem skozi leto. V raziskavi smo izbrali štiri različne črede ovac in koz (dve za vsako vrsto) in opazovali njihovo prostorsko razporeditev z ročnim GPS spomladi, poleti in jeseni. Istočasno smo tri živali v vsaki čredi neposredno opazovali pri paši. Podatke o času in natančno karto rabe tal smo obdelali v GIS-u, da smo dobili povezavo med aktivnostmi živali in različnimi krmnimi rastlinami. Ovce in koze so prehodile dolge razdalje (od 7,5 km do 9,0 km), da so v celotnem letu zadovoljile potrebe po hrani. Pasle so se na dveh glavnih tipih krme: pašnikih (travišča, grmišča in gozdni robovi) in kmetijskih površinah (prahe, strnišča in začasni pašniki). Obe vrsti sta se statistično značilno $(\mathrm{P} \leq 0.05)$ pasli krajši čas na pašnikih $(38,9 \%$ in $18,1 \%)$ kot na kmetijskih površinah $(63,6 \%$ in $53,4 \%)$ v spomladanskem in poletnem času. Očitno je, da je pestrost krajine nujna za ekstenzivne kmetijske sisteme z drobnico, saj se pašniki in kmetijske površine dopolnjujejo pri celoletni oskrbi s krmo.
\end{abstract}

Ključne besede: čreda, GIS, GPS, paša, pašniki, drobnica.

\section{INTRODUCTION}

Agro-pastoral land use depends to a great extent on movement patterns of grazing animals, which are related to the grazing season, the livestock species and forage availability (Schlecht et al. 2006). Additionally, when the flocks are shepherded, the habitat use and the animals' grazing behaviour are largely affected by the shepherd (Landau et al. 2000a). It has been mentioned by Rochon et al. (2009) and Sanon et al. (2007) that the shepherd acts as a manager since he forces his animals to explore larger areas in order to ensure the proper utilization of the rangelands. They also reported

\footnotetext{
${ }^{1}$ Department of Range Science, Wildlife and Freshwater Fisheries, Aristotle University of Thessaloniki, 54124 Thessaloniki, Greece. E-mail: katydata@for.auth.gr, yiak@for.auth.gr, vpapan@for.auth.gr

* Corresponding author
} 
that shepherds are aware of their grazing lands as well as forage quality and quantity.

Sheep and goat flocks following specific grazing circuits from sheds to rangelands and agricultural land come across an extremely heterogeneous environment, which dictates their grazing behaviour, especially feeding, moving and resting activities (Evangelou et al. 2008). The behavioural patterns of grazing animals are the result of inherited notions, experiences gained from individual and social learning systems or spatial memory (Launchbaugh \& Howery 2005). Through these mechanisms animals develop and revise preferences and aversions regarding specific feeding locations, patches, plant species and plant parts in the pastoral landscape.

In the Mediterranean environment, rangelands can provide forage to animals for only $6-7$ months during the year, mainly in spring and autumn (Yiakoulaki et al. 2003). To fill the feed gaps in between, other resources must be used, specifically temporary pastures during the winter period and cereal stubbles after crop harvesting in the summer (Evangelou et al. 2008). Research concerning the grazing behaviour of sheep and goats in such environments is focused on relatively homogeneous grazing areas, e.g. cereal stubbles after crop harvesting (Yiakoulaki et al. 2005), or on heterogeneous environments such as wooded rangelands of deciduous oak and beech trees (Yiakoulaki et al. 2009) and herbaceous and shrubby (Sarcopoterium spinosum) vegetation (Arnon et al. 2011). Data on grazing behaviour and movement patterns of sheep and goat flocks in the mosaic of different rangeland types and agricultural areas, which characterises the Mediterranean areas, does not exist to our knowledge. This information may be helpful to improve animal husbandry practices and to develop sustainable management schemes for these areas.

In this study the spatial distribution of representative flocks of sheep and goats as well as their grazing activities were recorded in a mosaic environment of communal Mediterranean rangelands (grasslands, shrublands and forest ranges) and in agricultural lands (1 to 5 year old fallows, cereal stubbles after harvesting and temporary pastures) during the year.

Figure 1: Grasslands (a), shrublands (b) and forest ranges (c) of the Askos village, Northern Greece.

Slika 1: Travišče (a), grmišče (b) in gozdni rob (c) pri vasi Askos, Severna Grčija.

\section{MATERIAL AND METHODS}

The research was conducted in the Askos village of the Lagadas County, located northeast of the city of Thessaloniki, Northern Greece, during three studied periods, spring and summer of 2007 and winter of 2008. The study area was 7885 ha in size. Mean annual precipitation is $581 \mathrm{~mm}$, and mean air temperature of the coldest month is $2{ }^{\circ} \mathrm{C}$, indicating a semi-arid Mediterranean climate. Topography varies from flat areas occupied by arable land to hills and mountains covered by natural vegetation. The latter is dominated by evergreen shrublands
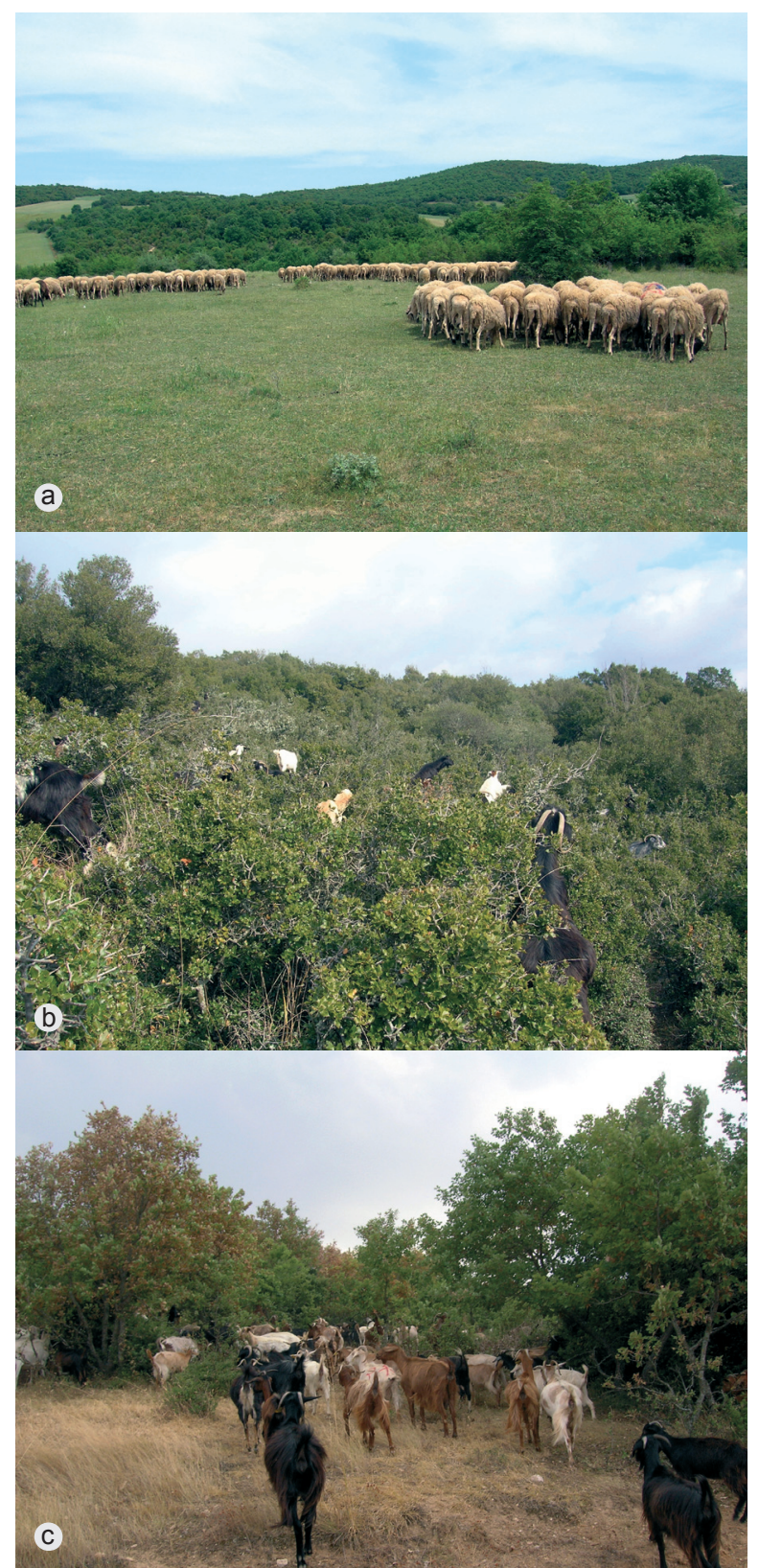
mainly composed of kermes oak (Quercus coccifera L.) interspersed with openings of herbaceous species (Lorent et al. 2008). The available resources were classified as rangelands, e.g grasslands (areas covered mainly by herbaceous species while woody species cover up to $10 \%$ ) and shrublands (areas with a shrub cover over $10 \%$ and a shrub height below $5 \mathrm{~m}$ ). Openings between shrubs ( $\mathrm{Pa}$ panastasis et al. 2008) support a large variety of herbaceous species and forest ranges (areas with overstorey vegetation occupied by Quercus frainetto with scattered individuals or groups up to $40 \%$ cover and height over $5 \mathrm{~m}$ ) (Figure 1).

Grazing agricultural land was also classified as fallow land (areas not cultivated for 1 to 5 years), cereal stubbles (annual crops after harvesting) and temporary pastures (winter cereals like Bromus, Secale and Triticum species grazed in late winter and early spring) (Figure 2). The studied animals were raised for milk and meat purposes. They were accompanied by shepherds to grazing sites during the largest part of the day and kept in sheds at night.

Animal activities of four representative sheep and goat flocks (two flocks of each species) were recorded in different seasons of the year. Among the flocks in the village with more than 100 animals, there were 5 pure sheep and 12 pure goat herds. A focal sampling technique (Altman 1974) was applied to twelve adult female animals (three sheep and goats from each flock), which were marked with large numbers on their sides for identification. Each flock was followed continuously by three observers for two consecutive days in each studied period. The observers were equipped with synchronised watches and onehour observation protocol forms, which were divided into six observation periods of 10 minutes each. Three animals were observed in sequence (two 10-minute observation periods per hour and animal). During the 10-minute observation periods, the animal grazing activities were recorded every 15 seconds. Observations started as soon as the animals had left the shed and been given enough time (15-20 minutes) to get used to the observers. Animals were left to graze freely without intervention, which resulted in spontaneous

Figure 2: Fallow land (a), cereal stubble field (b) and temporary pasture of winter cereals (c) in the Askos village, Northern Greece.

Slika 2: Praha (a), žitno stnišče (b) in občasni pašnik na ozimnem žitu (c) pri vasi Askos, Severna Grčija. visits of the different forage resources so that a random experimental design is assumed. At the end of the grazing day, when the flock returned to the shed, the observations were terminated. The recorded grazing activities were:

- feeding (the time that animals spent on grazing and browsing),

- moving (the time that animals spent on moving from one site to another without grazing),

- standing (the time that animals stood inactive),

- ruminating (time spent ruminating) and

- lying (the time animals were lying).
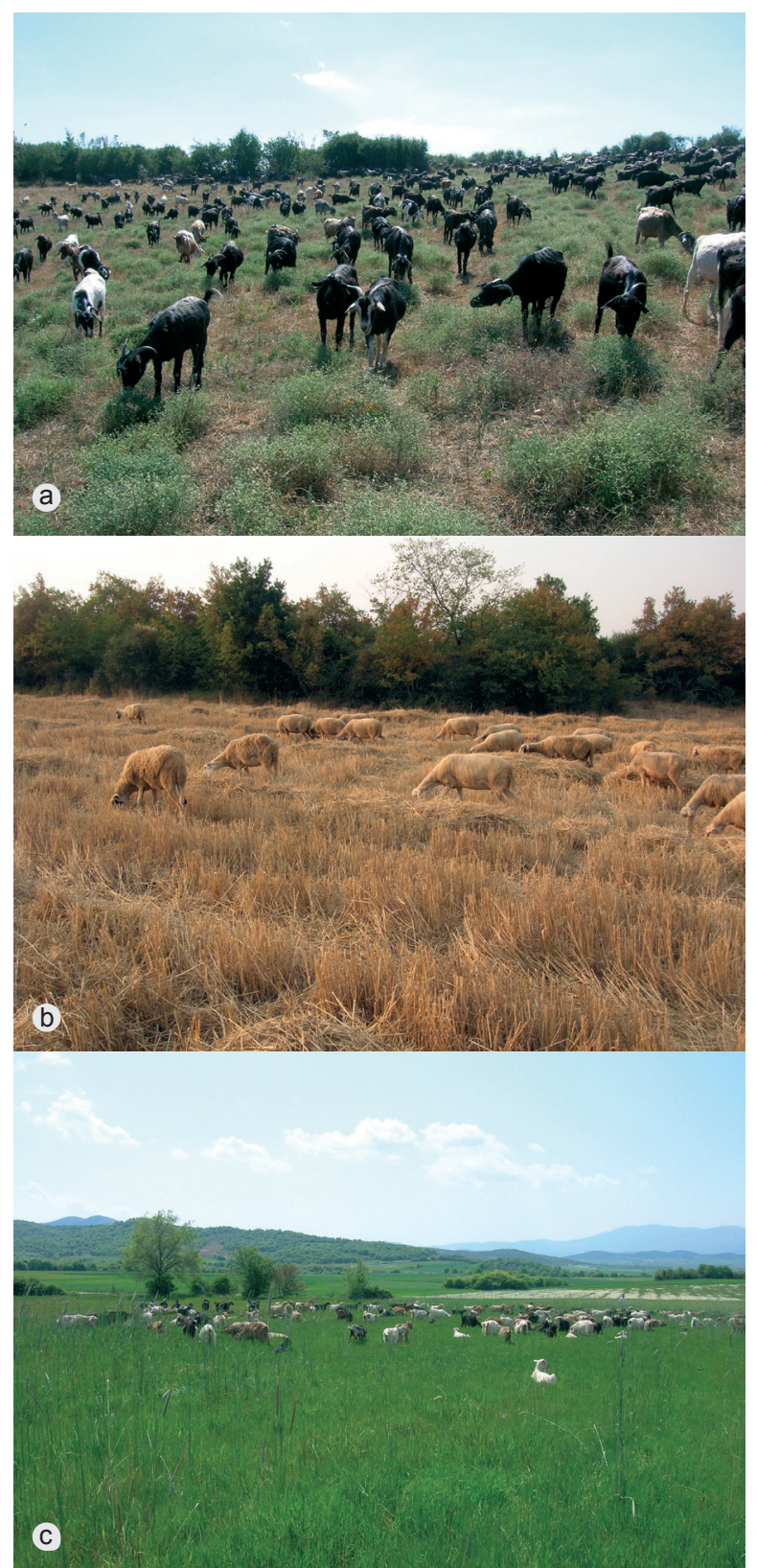
During the study period, the daily tracks of the flocks were recorded using a handheld GPS. These routes were imported into ArcGIS, and segments of 10-minute sampling intervals were detected. Each segment was overlaid with a detailed land use map, which was derived from IKONOS images (acquisition date November 2007) and combined with current land use records from the field. The category of forage resource that characterised each segment according to visual interpretation was finally inserted in the database. If a segment contained more than one land use unit, the most representative was selected. By merging the time information with the spatial observation obtained from the overlaid tracks, it was possible to relate the animals' activity to the land use units visited.

In total 1032 segments of 10-minute intervals were identified and overlaid with land use (313 in spring, 499 in summer and 220 in winter). Animal activities of each flock were grouped into percentages of time according to the season, grazer species and forage or type of resource. Data were tested for normality and arcsine transformed if necessary. Subsequently the average percentage of time spent by sheep and goats on each grazing activity and each forage resource (one average value per day) were subjected to analysis of variance with SPSS. When needed, the LSD test was applied for multiple comparisons (SPSS Inc. 2001).

\section{RESULTS}

The visual result of the 24 daily paths of the 4 flocks across rangelands and agricultural areas resulting from the sheep's and goats' daily foraging excursions overlaid on the land use/cover map is presented in Figure 3. According to the land use map, rangelands covered 4968.5 ha and agricultural areas 2224.6 ha $(63 \%$ and $28 \%$ of the total study area, respectively). Shrublands were the major rangeland type (74\%), followed by forest ranges $(22 \%)$, since grasslands were very scarce in the study area. Annual cereals covered almost $70 \%$ (10\% temporal pastures) while fallow land did not exceed $15 \%$ of the agricultural area.

Animals of both grazer species travelled long distances during the year to satisfy their daily forage requirements. More specifically, sheep and goats were found to travel their greatest distance during the summer period (8.5 and $12.0 \mathrm{~km}$, respectively). Goats covered longer distances in spring $(9.3 \mathrm{~km})$ than in winter $(5.6 \mathrm{~km})$ unlike sheep, who did the opposite, travelling $6.2 \mathrm{~km}$ in spring and $7.7 \mathrm{~km}$ in winter. However, on average goats travelled longer distances $(9.0 \mathrm{~km})$ than sheep $(7.5 \mathrm{~km})$.

Feeding was the most common activity irrespective of grazer species and forage resource. Converting the percentages of time of Table 1 into minutes per day, sheep spent more time (224.4 $\mathrm{min} /$ day $)$ on this activity than goats $(170.5 \mathrm{~min} /$

Table 1: Percentage (\%) of time per day spent by sheep and goats on animal activities in different forage resources during spring, summer and winter in Northern Greece.

Tabela 1: Delež (\%) časa na dan, ki ga porabijo ovce in koze za posamezne aktivnosti na različnih krmnih rastlinah spomladi, poleti in pozimi v severni Grčiji.

\begin{tabular}{|c|c|c|c|c|c|}
\hline \multirow{2}{*}{ Season } & \multirow{2}{*}{$\begin{array}{l}\text { Animal } \\
\text { activity }\end{array}$} & \multicolumn{2}{|c|}{ Grazer species } & \multicolumn{2}{|c|}{ Forage resource } \\
\hline & & Sheep & Goats & Rangelands & Agricultural land \\
\hline \multirow{4}{*}{ Spring } & Feeding & $61.9 \mathrm{a}^{1}$ & $40.6 \mathrm{~b}$ & $38.9 b^{1}$ & $63.6 \mathrm{a}$ \\
\hline & Moving & $19.4 b$ & $38.0 \mathrm{a}$ & $32.1 \mathrm{a}$ & $25.3 b$ \\
\hline & Ruminating & $1.8 \mathrm{a}$ & 4.9a & $3.2 \mathrm{a}$ & $3.6 \mathrm{a}$ \\
\hline & Standing & $16.9 \mathrm{a}$ & $14.3 \mathrm{a}$ & $25.2 \mathrm{a}$ & $6.1 \mathrm{~b}$ \\
\hline \multirow{4}{*}{ Summer } & Feeding & $31.4 \mathrm{~b}$ & $40.1 \mathrm{a}$ & $18.1 \mathrm{~b}$ & $53.4 \mathrm{a}$ \\
\hline & Moving & $24.6 \mathrm{~b}$ & $34.9 \mathrm{a}$ & $21.6 b$ & $38.0 \mathrm{a}$ \\
\hline & Ruminating & $0.2 \mathrm{~b}$ & $2.0 \mathrm{a}$ & $1.3 \mathrm{a}$ & $0.9 \mathrm{a}$ \\
\hline & Standing & $43.8 \mathrm{a}$ & $22.8 b$ & $58.9 \mathrm{a}$ & $7.7 \mathrm{~b}$ \\
\hline \multirow{4}{*}{ Winter } & Feeding & $57.8 \mathrm{a}$ & $52.2 \mathrm{a}$ & - & - \\
\hline & Moving & $34.7 \mathrm{a}$ & $33.5 \mathrm{a}$ & - & - \\
\hline & Ruminating & $0.2 \mathrm{~b}$ & $3.7 \mathrm{a}$ & - & - \\
\hline & Standing & $7.4 \mathrm{a}$ & $9.6 \mathrm{a}$ & - & - \\
\hline
\end{tabular}

${ }^{1}$ Means within the same row (grazer species or forage resource) followed by a common letter were not significantly different (P $\left.\leq 0.05\right)$. 


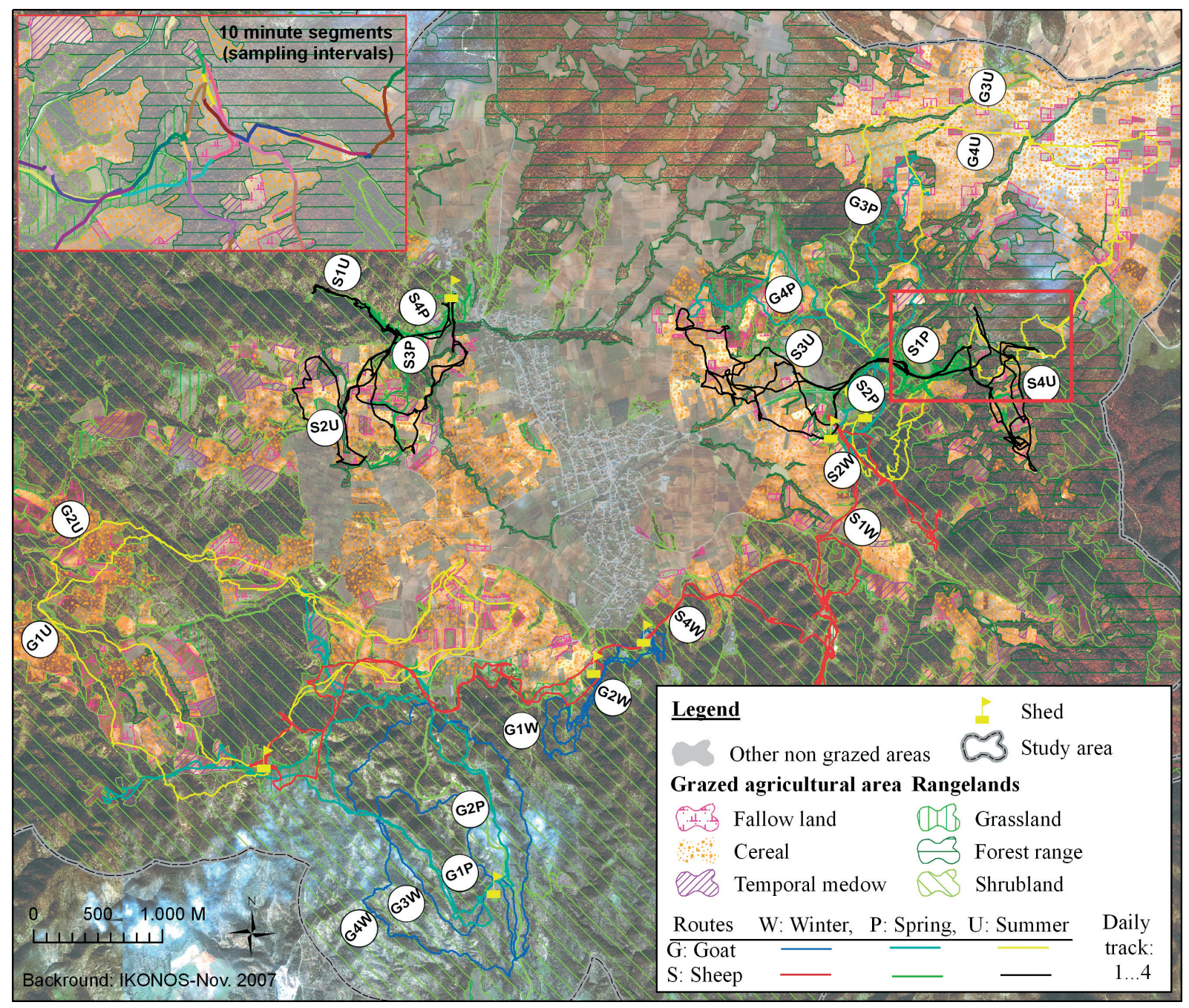

Figure 3: Land use/cover map overlaid by daily grazing routes of sheep and goat flocks.

Slika 3: Prekrivanje karte rabe tal/pokrovnosti in dnevnih poti čred ovc in koz med pašo.

day) in spring, while they spent less time (209.6 vs $232.6 \mathrm{~min}$ /day) on it in summer. In winter goats spent more time on feeding (157.9 min/day) than sheep (143.1 min/day), but with no significant difference. Taking the forage resource into account, it was found that both grazer species spent less time on this activity in rangelands than in agricultural land during spring and summer (Table 1).

On the contrary, grazing animals spent more time on moving and standing in rangelands during spring, while during summer they spent more time on moving and standing in agricultural land and rangelands, respectively. Time spent on rumination was not different between the two forage resources. Comparing the two grazer species, it was found that sheep spent more time on feed- ing than goats during spring, while the opposite happened in summer. During the winter period, sheep and goats were grazing only in rangelands, and the time spent on feeding was not significantly different between them. Goats spent more time on moving than sheep during spring and summer, while no significant difference was found in winter. In general goats spent more time ruminating than sheep, but statistically significant differences were found only in summer and winter. On the contrary, sheep were found to spend more time (293 min/day) on standing than goats (132 min/day) during summer. They also did not lie at all, while goats spent-albeit only a very small-part of the time (less than $2 \%$ ) on this activity. For this reason, this activity was not considered for further analysis. 
Table 2: Percentage (\%) of time per day spent by sheep and goats on animal activities in different resource types through the year in Northern Greece.

Tabela 2: Delež (\%) časa na dan, ki ga porabijo ovce in koze za posamezne aktivnosti na različnih krmnih rastlinah v celem letu v severni Grčiji.

\begin{tabular}{llrrccc}
\hline \multirow{2}{*}{ Resource } & Animal & \multicolumn{2}{c}{ Grazer species } & \multicolumn{3}{c}{ Resource type } \\
\cline { 2 - 6 } & activity & Sheep & Goats & Grasslands & Shrublands & Forest ranges \\
\hline \multirow{4}{*}{ Rangelands } & Feeding & $33.4 \mathrm{a}^{1}$ & $35.0 \mathrm{a}$ & $32.8 \mathrm{a}$ & $37.6 \mathrm{a}$ & $30.2 \mathrm{a}$ \\
& Moving & $31.9 \mathrm{a}$ & $40.7 \mathrm{a}$ & $34.9 \mathrm{a}$ & $34.0 \mathrm{a}$ & $43.7 \mathrm{a}$ \\
& Ruminating & $1.5 \mathrm{a}$ & $2.8 \mathrm{a}$ & $2.3 \mathrm{a}$ & $1.4 \mathrm{a}$ & $3.4 \mathrm{a}$ \\
& Standing & $33.3 \mathrm{a}$ & $20.5 \mathrm{a}$ & $29.5 \mathrm{a}$ & $26.5 \mathrm{a}$ & $22.3 \mathrm{a}$ \\
\cline { 2 - 6 } & & Sheep & Goats & Fallow & Stubble & Temporary pastures \\
\multirow{4}{*}{ Agricultural } & & & land & Fields & $60.5 \mathrm{a}$ \\
& Feeding & $66.6 \mathrm{a}$ & $49.8 \mathrm{~b}$ & $61.8 \mathrm{a}$ & $52.3 \mathrm{a}$ & $28.1 \mathrm{~b}$ \\
& Moving & $28.8 \mathrm{~b}$ & $35.9 \mathrm{a}$ & $29.9 \mathrm{~b}$ & $38.9 \mathrm{a}$ & $3.3 \mathrm{a}$ \\
& Ruminating & $0.0 \mathrm{~b}$ & $3.5 \mathrm{a}$ & $0.9 \mathrm{a}$ & $1.2 \mathrm{a}$ & $7.6 \mathrm{a}$ \\
\hline
\end{tabular}

${ }^{1}$ Means within the same row (grazer species or resource type) followed by a common letter were not significantly different $(\mathrm{P} \leq 0.05)$

The percentage of time spent on grazing activities by sheep and goats in different resource types of rangelands (grasslands, shrublands and forest ranges) and agricultural land (fallows, stubble fields and temporary pastures) is presented in Table 2. Irrespective of the grazer species, flocks spent more time on moving in cereal stubble fields during summer compared to fallow land and temporary pastures. For the remaining activities, there were no significant differences between the three resource types of agricultural land. In the agricultural land, sheep spent significantly more time on feeding than goats, while goats spent more time on moving and ruminating. No significant differences were found between sheep and goats in all grazing activities in rangelands, either as a whole or in each of the three resource types. Finally, the interaction between the grazer species and the resource type was found to be significant for the activity of moving in both resources.

\section{DISCUSSION}

The fact that goats generally travel longer distances than sheep to find grazing lands with the desired forage was also confirmed by $\mathrm{Lu}$ (1988). However, this does not apply to each season, especially if a specific forage resource is scarce. This can explain the longest distance that sheep were forced to cover during winter, a period with no stubble fields or temporal pastures to graze, the location of grasslands being far away from the animals' shed. In contrast, goats preferred to graze in the nearby shrublands. Similar results were also reported by Lieber et al. (2009). More specifically, they found that sheep extended the explored area in order to reach habitats dominated by species of the Poaceae family, which resulted in longer distances travelled per day in comparison to goats, which travelled shorter distances to the adjacent shrublands. Greater distances travelled by animals can often be attributed to the guidance of a shepherd, who affects animals' patterns (Schlecht et al. 2006) even without constant interference (Baumont et al. 2000). This is more pronounced at larger scale, where the shepherd decides on the major grazing lands in the landscape, while the animals, having reached these areas, are left uncontrolled to choose their feeding stations (Arnon et al. 2011).

The fact that both sheep and goat flocks spent more time on feeding in agricultural land than in rangelands during spring and summer justifies the integration of agricultural land in the production system as an alternative forage resource to rangelands. Schlecht et al. (2006) conducted a research in Western Niger (a non-Mediterranean environment) and found that grazing activities of herded sheep and goats showed seasonal differences depending on available forage resources (rangelands and agricultural land) and grazer species. For example, during the rainy season (June to September), herded goats spent more feeding time in rangelands than in agricultural land, while herded sheep did the opposite. 
The importance of fallow land as a forage resource for grazing animals, especially sheep, during the vegetative period has been reported by Glowacz et al. (2009). More specific, the forage production and the nutritive value of fallow land dominated by grasses (58\%) were variable during the vegetation period, reaching the highest yields in June and July. According to Chrupek et al. (2006), animals were found to spend more time grazing in fallows with lower walking speeds during this period. This fact seems to affect sheep grazing behaviour. Lower walking speed may increase feeding time and reduce moving time as happened in fallow lands of our study area. This also happened in temporary pastures, but not in cereal stubbles.

Additionally to fallow land, cereal stubbles play an important role in extensive small ruminant production systems from summer to early autumn. At this period forage of rangelands is dormant and depleted, and shepherds are forced to lead their flocks to barley and wheat stubbles for grazing (Yiakoulaki \& Papanastasis 2005). This is also a common practice of farmers in several parts of Southern Europe (Brand et al. 2000, Landau et al. 2000b, Correal et al. 2006). Stubble fields provide grazing animals with the remaining straw and the fallen grains. This feed of generally low nutritive value (Wales et al. 1990) is enriched by the presence of summer weeds such as Polygonum aviculare, Echinofora tenuifolia, Cynodon dactylon, Avena fatua, Chenopodium album etc., which usually appear after the rain (Brand et al. 2000, Yiakoulaki \& Papanastasis 2005, Correal et al. 2006). Weeds and especially forbs have been reported by Yiakoulaki \& Papanastasis $(2005,2006)$ as the main components of the diet selected by sheep (72\%) and goats (64\%) in cereal stubbles in Northern Greece, which resulted in the improvement of the nutritive value of the diet e.g. with respect to crude protein by $9.3 \%$ and $7.2 \%$ and regarding in vitro organic matter digestibility by $78 \%$ and $70 \%$ for sheep and goats, respectively.

Correal et al. (2006) state the use of whole cereal crops, which are used either directly as forage by grazing animals or cut at the end of the growing season to produce hay. These temporary pastures of annual winter cereals (e.g. barley, wheat, rye and oat; mainly as monocultures) are also important due to their significant contribution to milk production. They are used for grazing by lactating animals in late winter and early spring.
Animut et al. (2005) found that feeding time was longer for sheep than for goats. These authors also state that although the factors responsible for this are unknown, the botanical composition of the diet may be involved. However, in our study it seems that the harsh climatic conditions during summer affected the animals' grazing activities. Feeding time of sheep was reduced when temperature rose during the middle of the day, while the activity of standing was remarkably extended. Sheep formed groups and tried to hide behind each other to find protection against the sun. Goats, on the other hand, seemed less affected as they spent less time on standing during the hot hours of summer in comparison to sheep.

The rumination process allows animals to obtain nutrients from fibrous plant matter by reducing the particle size of feed. Rumination generally occurs when the animals are lying or standing. During rumination the animals are in a state of drowsiness, and there has been speculation about whether ruminants do actually sleep (Dwyer 2009). In this study the activity of rumination was the least frequent activity in both grazer species. This was probably due to the normal practice of the farmers to pen their animals during the night hours, giving them much time for rumination, but not for feeding. The longer ruminating time of goats in comparison to sheep is not in agreement with findings of other researchers (Domingue et al. 1991, Animut et al. 2005). It seems that the extremely heterogeneous environment of this study increases the need of goats to find time to ruminate.

Yiakoulaki et al. $(2005,2009)$ studied the grazing activities of mixed sheep and goat flocks in the same area, but with several forage resources (e.g. cereal stubbles and silvopastoral areas). The researchers reported higher proportions of feeding time (81\% for sheep and $77 \%$ for goats in cereal stubbles and $61 \%$ and $53 \%$, respectively, in wooded rangelands of deciduous oak and beech trees). Furthermore, they suggest that animals adapt their grazing behaviour to the environments in which they graze.

\section{CONCLUSIONS}

Animal activities were different depending on grazer species and season. Animals spent more time searching for food in rangelands than in agricultural land, and this was more pronounced 
during spring for goats and in summer for sheep. It appears that a heterogeneous landscape is necessary for supporting extensive farming systems of sheep and goats since rangelands and agricultural land complement each other in providing forage throughout the year. So it is of great importance to sustain a mosaic of resource types in rangelands, but this is not enough if agricultural lands are not also included.

\section{ACKNOWLEDGEMENTS}

The linguistic editing of the article by Dr. Aiko Huckauf is gratefully acknowledged. This research is part of the European research project DeSurvey (A Surveillance System for Assessing and Monitoring of Desertification - Contract No. GOCE-CT-2003-003950). The work of the first author was partially funded by a scholarship of the State Scholarships Foundation (IKY) of Greece.

\section{REFERENCES}

Altman, J. 1974: Observational study of behavior: Sampling methods. Behaviour 49: 227-267.

Animut, G., Goetsch, A.L., Aiken, G.E., Puchala, R., Detweiler, G., Krehbiel, C.R., Merkel, R.C., Sahlu, T., Dawson, L.J., Johnson, Z.B. \& Gipson, T.A. 2005: Grazing behavior and energy expenditure by sheep and goats co-grazing grass/forb pastures at three stocking rates. Small Ruminant Research 59: 191-201.

Arnon A., Svoray T. \& Ungar E.D. 2011: The spatial dimension of pastoral herding: A case from the Northern Negev. Israel Journal of Ecology \& Evolution 57: 129-149.

Baumont, R., Prache, S., Meuret, M. \& MorandFehr, P. 2000: How forage characteristics influence behavior and intake in small ruminants: a review. Livestock Production Science 64: 15-28.

Brand, T.S., Franck, F., Durand, A., \& Coetzee, J. 2000: The intake and nutritional status of sheep grazing wheat stubble. Small Ruminant Research 35: 29-38.

Chrupek, D., Groberek, J., Niznikowski, R., Brzostowski, H., Strzelec, E., Popielarczyk, D. \& Marciniec, M. 2006: Characteristics of Polish heath sheep grazing behavior on fallow lands during vegetative period, concerning pasturage time and weather conditions. Archiv Tierzucht 49: 353-358.
Correal, E., Robledo, A., Rios, S. \& Rivera, D. 2006: Mediterranean dryland mixed sheep-cereal systems. Grassland Science in Europe 11:14-26.

Domingue, B.M., Dellow, D.W. \& Barry, T.N. 1991: The efficiency of chewing during eating and ruminating in goats and sheep. British Journal of Nutrition 65: 355-363.

Dwyer, C. 2009: The Behaviour of Sheep and Goats. In: Jensen, P. (ed.): The Ethology of Domestic Animals - An Introductory Text. 2nd ed. CAB International, Wallingford, pp. 161-176.

Evangelou, C., Yiakoulaki, M.D. \& Papanastasis, V.P. 2008: Evaluation of sheep and goats breeding system and the subsidies paid in Askos village community of Lagadas county, Prefecture of Thessaloniki. In: Mantzanas, K. \& Papanastasis, V.P. (eds.): Range science and Protected Areas. Proceeding of the $6^{\text {th }}$ Panhellenic Rangeland Congress in Leonidio Arcadia Peloponnesus, pp.179-185.

Glowacz, K., Klimaszewski, K., Lozicki, A., Niznikowski, R., Poleszczuk, O., Popielarczyk, D. \& Strzelec, E. 2009: Botanical and chemical composition of fallow lands grazed by sheep under extensive conditions. In: Papachristou, T.G., Parissi, Z.M., Ben Salem, H. \& MorandFehr P. (eds.) Nutritional and foraging ecology of sheep and goats. Options Méditerranéennes 85: 129-133.

Landau, S., Provenza, F. \& Silanikove, N. 2000a: Feeding behaviour and utilization of vegetation by goats under extensive systems. In proceedings of 7 th International Conference on Goats, France, 15-21 May 2000, pp. 47-52.

Landau, S., Perevolotsky, A., Bonfil, D., Barkai, D. \& Silanikove, N. 2000b: Utilization of low quality resources by small ruminants in Mediterranean agro-pastoral systems: the case of browse and aftermath cereal stubble. Livestock Production Science 64: 39-49.

Launchbaugh, K.L. \& Howery, L.D. 2005: Understanding landscape use patterns of livestock as a consequence of foraging behavior. Rangeland Ecology and Management 58: 99-108.

Lieber, F., Kaulfers, C., Schmid, S., Kreuzer M. \& Liesegang, A. 2009: Differences in spatial grazing behaviour of sheep and goats in a heterogeneous high alpine environment. In: Agroscope Changins Wadenswil Research Station ACW (ed.) Integrated research for the sustainability of mountain pastures. Proceedings of 
the 15th Meeting of the FAO-CIHEAM Mountain Pastures Network, October 7-9, 2009, Les Diablerets, Switzerland, pp. 161-164.

Lorent, H., Evangelou, Ch., Stellmes, M., Hill, J., Papanastasis, V.P., Tsiourlis, G., Roeder, A. \& Lambin, E.F. 2008: Land degradation and economic conditions of agricultural households in a marginal region of northern Greece. Global and Planetary Change 64: 198-209.

Lu, C.D., 1988: Grazing behavior and diet selection of goats. Small Ruminant Research 1: 205-216.

Papanastasis, V.P., Yiakoulaki, M.D. Decandia, M. \& Dini-Papanastasi, O. 2008: Integrating woody species into livestock feeding in the Mediterranean areas of Europe. Animal Feed Science and Technology 140: 1-17.

Rochon, J.J., Duval, M. \& Goby, J.P. 2009: Effects on the environment of a flock of sheep when free ranging or under the guidance of a shepherd. Options Méditerranéennes 85: 61-65.

Sanon, H.O., Kabore-Zoungrana, C. \& Ledin, I. 2007: Behavior of goats, sheep and cattle and their selection of browse species on natural pasture in a Sahelian area. Small Ruminant Research 67: 64-74.

Schlecht, E., Hiernaux, P., Kadaoure, I., Hulsebusch, C. \& Mahler, F. 2006: A spatio-temporal analysis of forage availability and grazing and excretion behaviour of herded and free grazing cattle, sheep and goats in Western Niger. Agriculture, Ecosystems \& Environment 113: 226-242.

SPSS, Inc. 2001: SPSS Base 11.0 for Windows User's Guide. SPSS, Inc., Chicago, IL.

Wales, W.J., Doyle, P.T. \& Pearce, G.R. 1990: The Feeding Value of Cereal Straws for Sheep. I Wheat Straws. Animal Feed Science and Technology 29: 1-14.
Yiakoulaki, M.D., Zarovali, M.P., Ispikoudis, I. \& Papanastasis, V.P. 2003: Evaluation of small ruminants' production systems in the area of Lagadas County, Greece. In: Platis, P. \& Papachristou, T. (eds.). Range Science and Development of Mountainous Regions. Proceeding of the $3^{\text {rd }}$ Panhellenic Rangeland Congress in Karpenisi Greece, pp. 395-402.

Yiakoulaki, M.D., Pantazopoulos, Ch.I. \& Papanastasis, V.P. 2005: Sheep and goat behaviour grazing on stubble in northern Greece. In: Georgoudis, A. Rosati A. \& Monsconi C. (eds.) Animal production and natural resources utilisation in, the Mediterranean mountain areas. International Symposium, Ioannina, European Federation for Animal Science 115: 216-219.

Yiakoulaki, M.D. \& Papanastasis, V.P. 2005: Diet selection of sheep and goats grazing on cereal stubble in Northern Greece. In: Molina, A.E., Salem, B.H., Biala, K. \& Morand-Fehr P. (eds.). Sustainable grazing, Nutritional Utilization and quality of sheep and goat products. Options Mediterraneennes, Serie A, 67: 245-250.

Yiakoulaki, M.D. \& Papanastasis, V.P. 2006: Goats and sheep grazing on cereal stubble after harvesting. In Platis P.D., Sfougaris A.I, Papachristou T.G \& Tsiontsis A.I. (eds.) Rangelands of lowlands and semi- mountainous areas: means of rural development. Proceedings of the $4^{\text {th }}$ Panhellenic Rangeland Congress in Volos, Greece 10-12 November 2004, pp, 289-296.

Yiakoulaki, M.D., Zarovali, M.P. \& Papanastasis, V.P. 2009: Foraging behaviour of sheep and goats grazing on silvopastoral systems in Northern Greece. Options Mediterraneennes, Series A, 85: 79-84. 